\title{
Skam, maskulinitet och respons på mäns våld mot kvinnor
}

\author{
LUCAS GOTTZÉN
}

\begin{abstract}
Artikeln analyserar hur män som utövat våld mot kvinnor berättar om sitt våld för andra. Männen upplever våldet som skambelagt och är rädda för det sociala nätverkets respons. För att hantera ett förmodat förskjutande använder de sig av narrativa strategier som fördömer våldet samtidigt som mannen därigenom gör sig själv begriplig.
\end{abstract}

Mäns våld mot kvinnor fördöms allt hårdare från politiskt håll och ses idag som ett allvarligt socialt problem (Prop. 1997/98:55; Wendt Höjer 2002). Även i media fördöms våld i nära relationer. Våldsutövande män pekas då inte sällan ut som psykiskt sjuka eller på andra sätt avvikande från "normala" svenska män (Gottzén \& Jonsson 2012). Samtidigt fortsätter mäns våld mot kvinnor vara förhållandevis vanligt i Sverige, även om våldets faktiska omfattning både är svår att mäta och omdiskuterad. Vissa studier uppger att två procent (Brå 2013) andra att

Lucas Gottzén, docent och universitetslektor i socialt arbete verksam vid Linköpings universitet och Uppsala universitet. så många som fem procent av Sveriges kvinnor har utsatts för fysiskt våld under det sista kalenderåret (Lundgren et al. 2001). Vi har alltså en något paradoxal situation där mäns våld mot kvinnor fördöms samtidigt som det fortgår "i det privata". Även om mäns våld mot kvinnor i nära relation ofta utövas i det privata sker det alltid i ett socialt sammanhang. Ibland kan andra människor bevittna våldet (t.ex. på fest eller på krogen), och ofta får någon eller några i offrets eller förövarens närhet viss kunskap om vad som hänt. Ibland sprids det också rykten om våldet (Gottzén 2012). Våldsutsatta kvinnor och våldsutövande män kan också söka råd och stöd från det sociala nätverket, det vill säga från vänner, 
familj, arbetskamrater och andra bekanta (Ashley \& Foshee 2005; German 2006; Gottzén \& Korkmaz 2013; Hearn 1998a, 1998b; Hydén 2005; Klein 2012; Schwartz \& Dekeseredy 1997). Det är i relation till detta viktigt att undersöka hur de män som utövar detta våld ser på sina handlingar och hur de berättar om det för andra, eftersom det kan belysa hur våldshandlingar hanteras och offentliggörs till människor runt förövaren, och hur de kan fortsätta att hållas privata.

Ett sätt att närma sig frågan om det privata våldets offentliggörande är att rikta fokus på våldsutövande mäns beskrivningar av den skam de upplevt i relation till sitt våld. Skam är en emotion som väcks ur andras förmodade negativa respons på individens överträdelse av sociala normer och att de "sociala banden" är i fara (Scheff 2003a). Skam kan utgöra en lins som synliggör normativa föreställningar om våld och hur våldet hanteras av förövaren och människor i hans närhet. Genom intervjuer med män som genomgår eller precis avslutat terapeutisk behandling för att ha varit fysiskt våldsamma mot sina partners är syftet att undersöka våldsutövande mäns förväntningar på, och erfarenheter av det sociala nätverkets respons, det vill säga hur människor i mannens närhet reagerar på och hanterar våldet. Syftet är också att analysera hur män berättar om sitt våld för andra och hur männens berättande påverkar nätverkets reella respons. På så sätt visar artikeln på att skam både kan utgöra ett hinder för att berätta om sitt våld och en resurs i berättandet.

I det följande kommer jag att först presentera tidigare forskning om män och våld samt artikelns analytiska ram. Efter material- och metodpresentation redovisas studiens resultat. Avslutningsvis diskuteras resultaten i ljuset av studiens teoretiska perspektiv.

\section{Mäns våld - orsak och respons}

Mäns våld mot kvinnor har studerats utifrån en rad olika perspektiv. Individualpsykologiska forskare har exempelvis främst förklarat mäns våld i patologiska termer. Våldets orsaker förläggs då inte sällan till barndomen, missbruk eller så ses våldet som kompensation för mannens upplevelse av otillräcklighet (Dutton 1995). Annan forskning, ofta av kriminologisk eller sociologisk art, har främst gett socioekonomiska förklaringar och bland annat påpekat att socialt utsatta kvinnor löper störst risk att utsättas för våld i nära relationer (Altonen m.fl. 2012). Radikalfeministiska forskare har också sökt förklaringar på samhällelig nivå, men då synliggjort att mäns våld mot kvinnor förekommer i alla samhällsgrupper och ser det primärt som ett uttryck för könsmakt, det vill säga en strukturell obalans mellan könen där mäns våld och hot om våld upprätthåller kvinnors generella underordning (Ptacek 1988). Interaktionistiska förklaringar till mäns våld har också presenterats, exempelvis att parets destruktiva interaktion kan leda fram till mannens våld eller att våld utgör försök att kontrollera kvinnan (Winstock 2007).

Mäns våld har även studerats inom ramen för feministiskt orienterad maskulinitetsforskning (DeKeseredy \& Schwartz 2005; Hearn 1998a; McCurry 2007; Mes- 
serschmidt 1993; Schrock \& Padavic 2007). Denna forskning har förklarat mäns våld i relation till maskulinitet, exempelvis att våld kan vara ett sätt att leva upp till maskulinitetsnormer när andra maktresurser inte finns tillgängliga (Connell 2002; Messerschmidt 1993). Maskulinitetsnormer existerar dock inte av sig själva, utan skapas och förhandlas i vardagliga relationer (Messerschmidt 1993). Eftersom nätverkets attityder och agerande påverkar individens egna åsikter och handlingar (Fine \& Kleinman 1983) är familjens, vänners och andras respons - eller förmodade respons - på våldet därför viktigt för hur förövare agerar (Klein 2012). Risken är exempelvis större för en ung man att utöva våld i nära relation om hans vänner uppvisar åsikter som legitimerar mäns kontroll och våld mot kvinnor (Schwartz \& DeKeseredy 1997). Manliga vänner kan ge våldsutövare informellt stöd för våldet genom att uppvisa attityder och normer som stöder mäns dominerande av kvinnor i relationer. Vänner kan också ge emotionellt stöd genom att försäkra mannens rätt till kontroll. Slutligen kan vänner ge materiellt stöd genom pengar eller andra former av konkret hjälp för aktiviteter som underblåser patriarkal ideologi och kvinnoförnedring, så som porr, strippshower och alkohol. Detta stöd kan uppmuntra och legitimera mäns våld mot kvinnor (Schwartz \& DeKeseredy 1997). Hearn (1998b) skiljer på stöd som upprätthåller våld och stöd som syftar till att få våldet att upphöra. I hans studie var det dock få av männens familjer och vänner som direkt agerade eller stöttade mannen för att få våldet att upphöra. Snarare underblåstes våldet genom ett direkt och ensidigt för- svar av mannens agerande eller indirekt genom ignorans. Inte sällan hade dock familj, släkt och vänner ingen kännedom om våldet eftersom mannen var försiktig med att berätta om sina handlingar. I Germans (2006) studie av våldsutövande män i terapi, sökte en majoritet av männen emotionellt stöd från vänner och familj för att lära sig att sluta använda våld och hantera sina aggressioner. De upplevde dock sällan odelat stöd utan möttes ofta av moraliskt fördömande, eller en kombination av kritik och stöd, vilket männen inte upplevde hjälpte dem i deras process. Männen sökte också emotionellt stöd för att hantera upplevelsen av skam och det stigmatiserande utpekandet som kvinnomisshandlare (German 2006; jfr Gottzén 2012).

\section{Skam, maskulinitet och våld}

Artikelns analytiska fokus ligger på hur våldsutövande män redogör för sina skamupplevelser som det kopplar till sitt våld. Även om skam upplevs individuellt och kroppsligt är det i hög grad en social och relationell emotion eftersom det utgör en reaktion på andras reella eller förmodade handlingar (Hochschild 1983; Katz 1999; Scheff 2003a). I stället för att vara förenat med självfördömande tycks skamkänslor primärt vara beroende av reell eller förmodad negativ respons från andra. Skam grundar sig i att individen ser sig själv negativt genom andras ögon, eller utvärderas negativt av andra (Leeming \& Boyle 2013; Scheff 2003a). Det har poängterats att medan skuldkänslor kan uppstå när individen har agerat moraliskt fel, uppstår skam när 
överträdelsen är kopplad till jaget (Leeming \& Boyle 2013). Detta eftersom när jaget kopplas till den skamliga handlingen riskerar individen - eller tror sig riskera - relationen till signifikanta andra. Skam uppstår alltså i situationer där det finns ett verkligt eller inbillat hot mot sociala band (Scheff 2003a), vilket synliggör individens rädsla för uteslutning ur gemenskapen - att inte längre tillhöra ett imaginärt Vi utan förpassas till de obegripliga Andra.

Skam upplevs eller uppfattas dock inte nödvändigtvis som sådant för den enskilde, utan kan delvis vara omedvetet (Lewis 1992; Scheff \& Retzinger 1991). Enligt Scheff (2003a) pendlar vi ständigt mellan känslor av skam och stolthet, men skam är ofta tabubelagt och svårt att artikulera eftersom de kräver att den enskilde erkänner sig själv som otillräcklig, underlägsen och moraliskt bristfällig. När skam undertrycks kan det istället orsaka ilska, raseri och ibland våld (Scheff 2003b; Scheff \& Retzinger 1991). Scheff (2003b) ser skam som en central emotion för att förstå mäns våld. Han påpekar att skam är särskilt tabubelagt för män eftersom de ofta socialiseras till att trycka ned alla tecken på svaghet. Istället för att acceptera skam genom ett undandragande svarar män på statusförlust genom att visa ilska och ibland genom att ta till våld.

Medan Scheff menar att mäns förtryckta skamkänslor kan leda till våld, har feministisk forskning studerat kvinnliga våldsoffers upplevelse av skam (Enander 2010; Fiene 1995; Hydén 2005). Exempelvis har Enander (2010) i ett svenskt sammanhang visat på att våldsutsatta medelklasskvinnor är självanklagande och skäms för sin posi- tion som våldsoffer. De beskriver sig själva som "dumma", bland annat på grund av att ha funnit sig i det destruktiva förhållandet och stannat kvar. Andras dömande kommentarer kan också få kvinnor att känna sig dumma. Dessa erfarenheter av "könad" skam menar Enander (2010) är relaterade till att offren ser sig själva genom andras ögon och relaterar till föreställningar om jämställdhet, där kvinnor förväntas vara självständiga och inte har några formella skäl att stanna i våldsamma relationer. Att stanna kan därför ses som uttryck för att man inte lever upp till kulturella förväntningar på en "positiv" svensk kvinnlighet, enligt Enander. Skam och rädsla för vad andra förmodas tro kan utgöra hinder för såväl kvinnliga (Fiene 1995) som manliga (Weiss 2010) våldsoffer att berätta om sina erfarenheter för andra. De manliga sexualbrottsoffer Weiss (2010) har intervjuat är ofta självanklagande och rädda för vad andra ska tycka. Dessa skamkänslor menar Weiss kan kopplas till kulturella könsnormer, särskilt en rädsla för avmaskulinisering. Manliga sexualvåldsoffer lever inte upp till lokala maskulinitetsnormer eftersom "riktiga" män enligt dessa normer inte är offer, blir våldtagna eller visar sig svaga.

Denna artikel bygger vidare på tidigare forskning om skam, våld och genus genom att visa på hur våldsutövande mäns skam - i likhet med våldsutsatta mäns och kvinnors - relaterar till att de bryter mot genusnormer och därmed riskerar, eller tror sig riskera de sociala banden. Men samtidigt som skam kan ses som ett resultat av att sociala band hotas när individen överträtt moraliska gränser - genom att exempelvis utövat våld mot partner - menar jag att skamkäns- 
lan samtidigt synliggör handlingen som moraliskt problematisk. Men det räcker inte att uppleva och erkänna skammen inombords. Eftersom skam är en relationell och social emotion måste den uppvisas för en publik för att få social effekt (Goffman 1970). Det är viktigt att andra uppfattar skammen och "inser" att förövaren är genuint ångerfull, vilket exempelvis uppmärksammats i forskning om brottsmedling där tanken är att mötet med offret ska få förövaren att skämmas och ångra sitt brott (Braithwaite 1989; Karstedt 2002). Genom att verbalt eller icke-verbalt uppvisa rätt känsla vid medlingskonferensen synliggör förövaren att han inte fullständigt brutit mot normerna, trots allt. Skammens paradox ligger i att den kan - om korrekt uppvisad - återintegrera individen i köns- och våldsnormer i samma stund som han blir påkommen med att ha misslyckats leva upp till dem. Skam kan då utgöra en resurs för att berätta om sina moraliska felsteg, genom att i redogörelserna om sitt våld uppvisa skam kan mannen hantera andras förmodade fördömande.

Skam kan förstås som ett uttryck för förmodad respons på männens våld eftersom den framför allt är kopplad till en rädsla för att bli dömd och förskjuten av sitt sociala nätverk. Detta får konsekvenser för hur männen berättar om sitt våld för andra. Därför analyseras i denna artikel också hur männen berättar om sitt våld för familj, vänner och bekanta och dessas reella respons. Genom att fokusera på hur männen berättar om våldet för andra kan mäns perspektiv på sitt våld synliggöras och problematiseras. Männens redogörelser om förmodad och reell respons på deras våld synliggör också hur de relaterar till kulturella normer kring kön och våld i nära relationer, hur dessa normer används för att göra våldet meningsfullt, samt hur männen omförhandlar normativa föreställningar om kön och våld.

\section{Metod}

Det empiriska materialet är hämtat från ett större projekt om det sociala nätverkets respons på mäns våld mot kvinnor. Kontakten med projektets 44 män har jag fått genom behandlingsverksamheter på fem orter i Sverige, som bland annat är specialiserade på behandling av män som utövat våld. På vissa platser utgör mansverksamheten en av flera behandlande insatser mot våld i nära relationer, där även våldsutsatta kvinnor och barn får stöd. I andra fall utgör det en del av en mer generell behandlings- och stödverksamhet för män i kris. Liksom många andra liknande verksamheter i Sverige är de till stor del inspirerade av norska Alternativ til vold, en halvstrukturerad behandlingsmodell som kombinerar könsmaktsperspektiv med individuella förklaringar.

Urvalet är en form av bekvämlighetsur-

1 Projektet Mäns våld mot kvinnor $i$ nära relationer: En studie av förövarnas sociala nätverk finansieras av Forskningsrådet för arbetsliv och socialvetenskap och ingår i den större forskningsplattformen Responser på interpersonellt våld (RIV), som leds av professor Margareta Hydén, Linköpings universitet. Jag vill rikta ett särskilt tack till terapeuterna och de medverkande männen utan vars hjälp detta projekt inte vore möjligt. 
val, där behandlarna erbjöd män i verksamheten som utövat fysisk våld mot partner vid åtminstone ett tillfälle möjlighet till intervju och sedan bokade tid med dem och mig. ${ }^{2}$ Männen deltar, eller har deltagit, i så kallad mansgrupp och/eller enskilda samtal "frivilligt", det vill säga de har inte blivit dömda till behandling utan sökt sig till det på eget initiativ eller på uppmaning från partners, socialtjänst eller polis. Vissa män har dock blivit anmälda, eller har tidigare varit dömda för olaga hot, misshandel eller kvinnofridskränkning. Som tabell 1 visar så har samtliga män enligt egen uppgift använt sig av "lindrigt" fysiskt våld (knuffa omkull, örfil, ta tag i hårt, etc.), en knapp tredjedel har dessutom använt grovt fysiskt våld (stryptag, sparkar, knytnävsslag, slag med tillhyggen, etc.). Majoriteten har utövat fysiskt våld vid fem eller fler tillfällen.

Majoritetssvenska män från arbetaroch medelklass utan tidigare kriminell belastning eller missbruk är i majoritet bland deltagarna. Lite mer än hälften av männen har som högst gymnasieutbildning och en knapp tredjedel har högskoleutbildning. Männen är mellan 17 och 66 år, medelåldern är 36 år. De flesta män (75 \%) är dock mellan 25 och 45 år.

Studien är inspirerad av narrativ metod (Riessman 2008). Det innebär, för det första, att jag genomfört berättarfokuserade intervjuer (Hydén 2000). Dessa liknar

2 Sammanlagt intervjuade jag 52 män, men åtta av dessa har dock inte inkluderats i studien eftersom de vid intervjun uppgav att de inte hade varit fysiskt våldsamma mot partner eller att de inte hade varit i behandling på över tre månader. semistrukutrerade intervjuer men är något öppnare till sin karaktär. I den berättarfokuserade intervjun är forskarens uppgift att underlätta och aktivera informantens berättande. Detta innebär att jag ställer frågor till mannen om exempelvis hur det kommer sig att han började i terapi, om han kan ge exempel på när han har varit fysiskt våldsam, om vem han har berättat för om våldet och om han kan ge exempel på när han gjort det. Intervjuerna genomfördes 2009-2012 och varade mellan en och två timmar. Intervjuerna har transkriberats

\section{Tabell I.}

Informanternas bakgrund och våldsutövande.

\begin{tabular}{lc}
\hline Deltagare $(\mathrm{N}=44)$ & Antal \\
\hline Utbildning & \\
Högskola & 14 \\
Gymnasium & 26 \\
Grundskola & 4 \\
Ursprung & \\
Sverige, båda föräldrar inrikes födda & 34 \\
Sverige, minst en utrikesfödd för- & 7 \\
älder & \\
Utrikesfödd & 3 \\
Kriminalitet & \\
Annan kriminell belastning & 10 \\
Ingen annan kriminell belastning & 34 \\
Missbruk & \\
Missbruk eller tidigare missbruk & 12 \\
Inget missbruksproblem & 32 \\
Fysiskt våld & \\
Lindrigt våld & \\
Lindrigt och grovt våld & 30 \\
I-4 tillfällen & 14 \\
>5 tillfällen & \\
\hline & \\
&
\end{tabular}


och därefter kodats. Kodningen har varit tematisk, fokuserat på utsagornas innehåll, vilket möjliggjort en överblick av det empiriska materialet.

Studiens narrativa ansats synliggörs, för det andra, i analysen av männens utsagor. Men där mycket narrativ forskning fokuserar på berättelsers form och innehåll (Riessman 2008) studerar jag här de våldsamma männens narrativa arbete (Gubrium \& Holstein 2008). Det vill säga, jag intresserar mig för hur de har berättat om sitt våld för andra - vilka versioner av våldet och hur de valt att berätta för vem. Det bör påpekas att det endast är männens egna redogörelser för sitt narrativa arbete jag har tillgång till. Dessa redogörelser utgör inte evidens för deras erfarenheter, utan bör snarare förstås som narrativt arbete i själva intervjun, det vill säga försök att framställa sig själva som moraliska subjekt (Gottzén 2013).

För denna artikel har tre olika former av redogörelser studerats. För det första har männens redogörelser om skam analyserats. Alla män menar att de tyckte att det var jobbigt att berätta om sitt våld, men alla pratar inte om det i termer av skam. Många beskrev våldet som "pinsamt", "skämmigt" och att det var "ångestfyllt" att berätta. De män som talade om skam eller använde något av dessa andra relaterade begrepp bad jag vidareutveckla sina resonemang. För det andra så analyseras de redogörelser för de sociala nätverkens respons som männen i studien ger. Dessa reaktioner delades upp i tre kategorier: renodlat kritisk/fördömande, icke-fördömande respons samt en kombination av dessa positioner. De flesta män hade mött sistnämnda respons. Slutligen har männens narrativa strategier analyserats, det vill säga de olika sätt de valt att berätta om sitt våld för andra (Waldram 2010). Beskrivningarna av dessa strukturerade sätt att berätta har uppkommit utifrån att jag bett männen återge om hur de berättat om sitt våld. Jag gör en analytisk skillnad mellan strategier som syftar till att undvika utpekandet som skamlig våldsman och de som använder skammen som en retorisk resurs för att begripliggöra mannen. De män som presenteras i denna artikel har valts ut därför att de exemplifierar någon av ovan nämnda kategorier och strategier utförligt. Namn på personer och platser har fingerats för att bevara männens anonymitet.

\section{Resultat}

I det följande presenteras studiens resultat. Först lyfts männens förståelse av våld och vad de förmodar är nätverkets respons fram, sedan presenteras den reella respons männen menar att de fått. Slutligen diskuteras de narrativa strategier som utgör resurser för männens hanterande av vad de upplever vara våldets skamlighet.

\section{Skam och förmodad respons}

Innan Bengt, 40 år, slog sin sambo för första gången såg han sig själv som en lugn och eftertänksam man. En man som inte tar till våld, vare sig mot män eller kvinnor. Knuffarna och slagen beskriver han som kulmen på otaliga bråk med sambon, bråk som bottnade i deras ekonomiskt pressade situation. Han är noga med att påpeka sin eget ansvar 
till våldet, vilket är något han skäms för: "Första gången, ja, var inte så jätterolig. Då kände jag skam." När jag ber Bengt utveckla vad det var han upplevde skamfyllt beskriver han sin förutfattade mening om kvinnomisshandlare och hur han relaterar till kategorin. $^{3}$

Eh att kvinnomisshandel, att jag sett en kategori framför mig, vilka som gör det här. Jag har inte kunnat placera mig i det här. [...] Så det tyckte jag, att det var direkt pinsamt.

Bengt är inte ensam om att tycka att kvinnomisshandlaren är en problematisk kategori som han inte vill känna sig vid. Alla män jag intervjuat menar att våld mot kvinnor är moraliskt förkastligt och många ser "kvinnomisshandel" som ytterst skamfyllt. För Bengt handlar skammen till viss del om att han inte ser sig som en våldsam person, men han ser det också som ett misslyckande som partner. Han skäms för att han inte lyckats prata sig ur konflikter och att han därmed går över gränsen för vad han anser vara god kommunikation med den man älskar.

För andra män handlar våldets skam-

3 Begreppet kvinnomisshandel används inte längre i någon större utsträckning bland forskare, politiker och praktiker. Populärare begrepp är "(mäns) våld mot kvinnor" och "våld i nära relationer". I denna artikel används begreppet eftersom det är ett så kallat emiskt begrepp, det är en term som har sin speciella betydelse i den givna kontexten. Männen i studien använder sig av kvinnomisshandlarbegreppet ofta, framför allt för att tala om sin skam och som en kategori de vill distansera sig från. lighet om att det går på tvärs med våldsnormer, särskilt idén om att man inte ska ge sig på den som är svagare. Män anses därför kunna utöva visst våld mot andra män, medan kvinnovåld inte är ett legitimt inslag i maskulinitetsgörandet (jfr Gottzén 2012). Som Lars, 31 år, påpekar: "Våldtäktsman och kvinnomisshandlare, där är det nästan bättre att va en känd mördare”. Att kvinnomisshandlaren upplevs som en maskulin avvikare är avgörande för hur männen hanterar sitt eget våld. 25-årige Björn, som återkommande har försökt strypa sin före detta flickvän, undviker exempelvis att nämna sitt våld för sina vänner. Hans vänner, likt han själv, fördömer kvinnovåld och han tror att de därför inte kommer reagera särskilt positivt.

Alltså, ja det är väl det för att man vill inte tänka så om sig själv. Det är väl den största anledningen. Det är förbannat grisigt och svinigt att ta övertaget mot en kvinna, men va fan, dom är så mycket svagare. Det finns ju fan inget skit dom kan göra åt det att en kille hoppar på dom. Finns ingenting, inget sätt dom kan ta sig ur situationen - ifall dom nu inte är bodybuilders. Så det är så jävla grisigt så det inte är sant, så varför skulle jag vilja säga det till mina vänner?

Björns uttalande synliggör relationen mellan hans egen självförståelse, vad han tror är den gängse synen på kvinnovåld och hur andra därmed kan uppfatta hans våldsutövande. Eftersom våld mot kvinnor är förkastligt vill han vare sig se sig själv eller att andra ska uppfatta honom - som en kvinnomisshandlare. Gustav, 24 år, för ett 
liknande resonemang kring rädslan om vad närstående ska tycka om de knuffar och slag han gett sin flickvän.

Finns många som säkert skulle säga upp kontakten om det fick reda på att man har aggressionsproblem. Slà en annan kvinna också, eller skrämma en annan kvinna är inte heller okej. Det är nåt som ses, inte ovanligt att ses, ja lägst i botten liksom. Det är det mest moraliska fel man kan göra på nåt sätt. Mer okej att slå någon på krogen eller ta en stöld eller nåt sånt men aldrig mot en kvinna, svagare människa rent fysiskt och dessutom den man älskar. Hur lågt kan man gå? Skulle många tänka. Kan jag tänka mig. Eller [det är] min rädsla.

Gustav poängterar vad han förmodar är andras uppfattning om våld mot kvinnor, att det är moraliskt förkastligt. Om hans vänner och bekanta skulle få reda på vad han gjort tror han att de skulle säga upp bekantskapen. Upplevelsen av skam gör att han inte heller berättar för sin familj.

Mestadels skäms jag över det. Ja, skäms att säga, liksom rädsla för hur dom ska betrakta mig om jag säger det. Hur relationerna kommer bli, om det kommer bli sämre eller dom kommer se ned på mig eller förakta mig eller så. [...] Nej, liksom att ha en familj som skäms för mig, eller att Lisas familj ska stöta bort mig liksom. [...] För jag skulle nog göra så.

I linje med Sheffs (2003a) resonemang om att skam uppstår när de sociala banden riskeras, är männens upplevelse av skam kopplad till rädslan att bli fördömd och förskjuten. Detta gäller exempelvis Samuel, 44 år, som inte berättat för någon om att han knuffat och tryckt ned sin sambo. Han har valt att inte berätta eftersom det är något han skäms över och för att han är "rädd för att bli ratad". Han tror att hans vänner inte skulle kunna hantera informationen och att han troligtvis inte längre "hade blivit accepterad i den gemenskapen". Det gäller också 60-årige Nils, som "drar sig för" att berätta om att han knuffat, tagit tag i och kastat saker på sin sambo eftersom han tror att han "kommer nog bli ännu mer dömd" än vad han redan känner sig.

Männens skam handlar om att sociala relationer riskeras som en följd av att könade normer för våld överträtts. De normer som överträtts gäller dels betydelsen av ömsesidig respekt och kommunikation i parrelationer, men kanske framför allt att en man inte förväntas utöva våld mot svagare individer, inklusive kvinnor. Det är utifrån dessa normer, som männen själva skriver under på, som männen resonerar kring förmodad respons från vänner, familj och bekanta. Skam tycks alltså vara kopplat till att männen, när de ser sig själva i andras ögon, tror att de kommer att ses som det maskulina subjekt de själva tar avstånd från -kvinnomisshandlaren.

\section{Reell respons på mäns våld}

Männen i studien är ofta tveksamma till att berätta om sitt våld. När de utgår från sin egen och vad de tror är andras förståelse av mäns våld mot kvinnor förmodar de att deras vänner, bekanta och 
familj kommer att respondera på våldet med kritik, avståndstagande och fördömande. Samtidigt vill många av männen berätta om sitt våld för åtminstone någon eller några närstående. Anledningarna till detta varierar. Det kan baseras på ett upplevt behov av att "prata av sig". Det kan också handla om att söka stöd i en tid av kris, då särskilt att försöka förstå sitt beteende (jfr German 2006). I vissa fall handlar det också om att försöka föregå ryktesspridning. Med tanke på att våldet upplevs som skamligt är det dock inte helt enkelt att berätta. En del av männen har fått fördömande eller avståndstagande reaktioner.

Jag träffade en tjej innan jag träffade min nuvarande tjej [...] och då berättade jag ju sakta men säkert och förklarade att jag var dömd för misshandel. Och sen ganska snabbt var hon ju intresserad: "Är det mer än en gång?" Och sen när hon fick reda på att ja, det är nog fler gånger, då tappade ju hon ganska snabbt intresset. För då fattade hon att det här är en person med problem. (Pontus, 39 arr)

Pontus önskan om att berätta om sitt våld för sin flickvän kan ses som ett uttryck för samtida ideal kring parrelationer. För att en relation ska upplevas som "sann", hälsosam och utvecklas bör den bygga på öppen och ärlig kommunikation, vilket innefattar att dela med sig av obekväma hemligheter (Smart 2007). Att inte vara ärlig i en relation innebär då att bedra den andre och därmed riskera relationen. Men relationen riskeras också av att berätta om våldet, som Pontus erfarenhet visar.
Idealet om att vara öppen och ärlig gäller inte enbart partners, utan också nära vänner. Även då hotas de sociala banden, som det gjorde för Patrik, 39 år.

Jag har berättat det för en som jag trodde var, eller ja en vän som jag trodde var en vän och hans fru. Ja det var, komma dit och berätta det för en kompis, det var tufft. Och så tänkte jag, har man fätt höra att det är bra att göra det, så då gjorde jag det. Såblev det, då skulle de rädda Sara från mig dà när, ja när de pratade med henne på tu man hand då.

Patriks drivkraft till att berätta liknar till viss del Pontus, att han ville vara öppen och ärligt mot sin vän. Men det utgörs också av ett behov att "lätta på hjärtat", vilket uttrycker idén att om du går igenom en livskris eller mår psykiskt dåligt är det bra att kommunicera detta med någon. Berättandet och bekännelsens katarsis förmodas då att ha läkande kraft. Men för våldsutövande män är det inte alltid lätt att få det emotionella stöd de hoppas på (German 2006). Istället för att få hjälp att prata om och diskutera sitt beteende, upplevde Patrik att vännerna vände sig mot honom.

Även om en del vänner och bekanta tar avstånd när männen berättar om sitt våld är det få som fått sina värsta farhågor besannade. Andreas, 34 år, som bland annat knuffat och tryckt upp sin sambo mot väggen, började berätta om sitt våld i samband med separationen. Han upplevde ett behov av att berätta för vänner och familj om sitt våld, trots att han tyckte det var jobbigt. Jag frågar hur vänner och familj reagerat. 
Andreas: Alltså folk har inte sagt så mycket. Och jag vet faktiskt inte varför. Jag, jag vet inte.

Lucas: Vad menar du med att dom inte sagt så mycket?

Andreas: Dom har lyssnat "Jaha har du det? Åh vad hemskt" men sen inte mer.

Emil, 23 år, har en liknande upplevelse om när han berättade om sitt våld för en äldre vän. Han tyckte också det var jobbigt att berätta eftersom han var rädd för vad vännen skulle tro om honom.

Jag berättade vad, vad jag, vad som hade hänt mellan oss och jag berättade också vad jag hade gjort, men jag drog nog på det en del. [...] Så sa jag liksom att jag tagit tag $i$ henne och då tyckte han väl att ja, "Det är ju absolut inte okej. Absolut inte okej." Men han fräga om jag hade slagit henne och då sa jag "Nej det har jag absolut inte gjort." Och då sa han "Nej, men det är väl bra då."

När vännen får reda på att Emil "tagit tag i" sin flickvän påpekar han att det inte är en godtagbar handling. Sedan försäkrar han sig om att Emil inte slagit henne. När Emil kan bekräfta att det bara har skett vid ett tillfälle och att han inte har "slagit" henne kan hans agerande i viss mån accepteras. Även om våldet Emil utövat inte helt accepteras så begripliggörs det $-i$ synnerhet när det jämförs med "grövre" och återkommande våld. I en del fall - som för 32-årige David (som har knuffat, tagit hårt och slagit med öppen hand) - blir mannen och hans situation så pass begriplig att hans vänner helt tar hans parti. Liksom Emil menar David att hans vänner fördömt våldet,
"Alltså det säger alla, att man inte ska slåss" Men vännerna påpekar samtidigt den före detta flickvännens "speciella karaktär" och att David inte ska ta på sig skulden i relationen utan att problemen i relationen beror på henne. Eftersom våldet anses bottna $\mathrm{i}$ hennes beteende blir lösningen på våldet därmed främst att bryta upp från relationen.

David är inte ensam om denna typ av respons där våldet fördöms och begripliggörs i samma stund. Kritiken mjukas upp, våldet ignoreras och framstår som inte särskilt farligt, eller åtminstone inte som huvudproblemet. Det stöd männen i studien får är relativt olikt det Schwartz och Dekeseredy (1997) funnit bland manliga universitetsstudenter i USA, där ett relativt ensidigt stöd som uppmuntrar och försvarar mäns sexuella våld ges. De män jag intervjuat får sällan ett odelat stöd i att våldet är godtagbart, tvärtom, den initiala responsen utgörs oftast av ett tydligt avståndstagande till våldet. Men när våldet väl definierats som felaktigt diskuteras antingen inte frågan mer, eller så försäkrar sig vännen eller familjemedlemmen om att våldet inte är återkommande eller för grovt. Familjemedlemmar och vänner kan också lyfta fram betydelsen av partnern som bidragande orsak till våldet. Deras respons liknar därmed mer de Hearn (1998b) visar på, att familj och vänner ignorerar våldet och i stället väljer att prata om separationen eller andra problem mannen har.

Stöd och förståelse kan dock avta om våldet fortsätter. Pontus, exempelvis, har varit våldsam i många relationer och varit i rättegång för sitt våld vid flera tillfällen. Vid första tillfället upplevde han ett stort 
stöd, vilket han menar hade att göra med att han i samband med detta försökte begå självmord. Eftersom det var första gången sågs våldet också som något av en engångshändelse. Attityden till hans våld ändrades dock när våldet blev återkommande.

Men sen när man kommer till andra relationen och där det ett år senare slutar med samma sak. Och så blev det dessutom rättegång igen då, jag klarade mig i rättegången i första relationen, så blir det rättegång igen, då liksom tröttnade folk på det.

Pontus menar att han förlorat stora delar av sitt sociala nätverk och blivit allt mer socialt isolerad som en följd av att våldet fortsatt. Även om hans föräldrar inte tagit avstånd från honom så vill de inte längre få information om hans våld och medan hans mamma deltog i den första rättegången kom hon inte på rättegången efter andra relationen.

\section{Narrativa strategier}

Hur kan man förklara att de flesta män upplever så pass "positiv" respons, trots att de förmodar att de kommer att bli utstötta på grund av sina handlingar? Till viss del beror det, som jag visat, på våldets omfattning och karaktär. Vissa mäns våld görs begripligt eftersom de inte utövat vad som uppfattas som grovt våld eller i alla fall inte under längre tid. Detta våld ses som uttryck för bråk mellan mer eller mindre jämställda partners och därmed inte som "riktig" kvinnomisshandel (jfr Eriksson 2003; Hydén 1995). Men de sociala nätverkens respons är också beroende av hur männen presenterar sitt våld. Det finns en rad olika narrativa strategier till hands för männen när de berättar om sina handlingar. Narrativa strategier kan förstås som strukturerade sätt att kommunicera betydelse genom och i berättelser, i synnerhet försök att kommunicera något specifikt om berättarens karaktär (Waldram 2010). Männen kan exempelvis omdefiniera våldet genom att tala om sitt våld i termer av "aggressionsproblem" eller "impulskontroll" snarare än om fysiskt våld (jfr Hearn 1998a), eller välja tala om att de ha varit "fysiskt våldsamma" men undvika begrepp som "kvinnomisshandel", vilket indikerar ett mer systematiskt och grövre våld (jfr Gottzén 2012). Dessa omdefinieringar handlar om att beskriva våldet från sitt eget perspektiv. 66-årige Christer (som knuffat, tagit i hårt och örfilat sin fru) menar exempelvis att hans vänners okritiska reaktioner beror på hur han beskrivit sitt våld.

Om jag har talat om situationen, och jag berättat om situationen för mig, så kanske en del av det man berättar speglar litegrann av hur man själv har, tycker att situationen har varit. För det är ju de ord man använder och hur man berättar, det speglar ju litegrann av ens inställning till vad som har hänt. [...] Om jag skulle använda ord som att "jag var väldigt våldsam", "jag var nästan på väg att slå ihjäl min fru" så hade det väl varit väldig reaktion.

En annan form av narrativ strategi utgörs av att kontextualisera våldet. När mannen berättar om sitt våld berättar han då också om sina psykiska problem, om hennes psy- 
kiska problem och humör, hennes provokation, sin egen allmänna krissituation, eller sin separation. Våldet görs därmed till endast ett av flera element i mannens övergripande berättelse och framställs som mindre betydelsefullt.

Att omdefiniera och kontextualisera kan ses som narrativa strategier som hjälper förövaren att hantera det förmodade utpekandet av honom som kvinnomisshandlare och våldet som skamligt. Men männen kan också använda skam som resurs när de berättar om sitt våld. En narrativ strategi blir då att i direkt samband med erkännandet av våldet fördöma sina egna handlingar. David förklarar hur det oftast har gått till när han berättat om sitt våld.

Det har inte vart så "Du hej, jag slog henne." "Jaha, det ska man inte göra." Det har absolut inte vart det utan det har kommit fram det att: "Ja, ja, vi bråka" "Vad hände?" "Ja, jag slog till henne, alltså jag har sån ångest för det, jag skulle inte gjort det" "Nej, man ska inte slåss." Det var alltid så.

David menar att han aldrig enbart sagt att han slog sin flickvän, utan att han alltid också bifogat att han ångrar det, och visar då att han tycker att han agerat fel och att han dömer ut sina egna handlingar. Genom att markera ett tydligt avståndstagande från sitt eget beteende kan David föregå omgivningens fördömanden. De kritiska kommentarerna om de egna handlingarna blir ett sätt att demonstrera att han verkligen förstått att han överträtt rådande våldsnormer. Härigenom kan David också placera in sig själv i den gemenskap som menar att mäns våld mot kvinnor är moraliskt proble- matiskt. Centralt är också att David påpekar att han "har sån ångest för" våldet, vilket även gäller Anton, 27 år. Han har varit våldsam vid upprepade tillfället, bland annat har han slagit, knuffat och sparkat på sin före detta sambo. Vid sista tillfället blev han arresterad och frånvarande från sitt arbete under flera dagar. När han släpptes åkte han direkt till arbetsplatsen och berättade för alla kollegor eftersom han trodde att det hela ändå skulle bli känt. Han var rädd för deras reaktioner. En del har varit kritiska, men han har fått stöd och uppmuntran från många för sin öppenhet och för att han börjat gå i terapi.

De vet ju att jag är ångerfull alltså, det har ju sett hur dåligt jag har mått. Jag rasade, jag tror jag gick ner nio kilo eller någonting första perioden i vikt. Àt inget, kunde inte sova, väldigt ångestfylld och mådde väldigt dåligt alltså och tog kontakt med Kvinnofrid här och började gå här då. [...] De vännerna jag pratar med de säger liksom det att "du är ju ångerfylld" [...] och det säger de även på jobbet att "Du visar ju ånger och du har ju tagit tag $i$ dina problem, och du är ju öppen med vad du har gjort. Det hade varit en sak om du hade förnekat och sagt att 'det är fan inte mitt fel, det är hennes fel' och allt det där. Du medger ju att du har ett problem och att du tar tag $i$ det. Det är många som har problem, men de tar aldrig tag i det."

Anton påtalar inte våldets skamlighet enbart verbalt, utan han visar även ånger kroppsligt: han har mått dåligt, han rasade i vikt, hade sömnproblem och var "väldigt ångestfylld". Vännerna uppfattar detta beteende som att vara "ångerfylld". Anton 
synliggör också sin ånger genom att erkänna sina fel och problem, och genom att "tagit tag i" dem genom att börja gå $i$ terapi. Även detta tas som uttryck för ånger genom att kontrastera Antons handlande mot om han hade förnekat sin skuld och sina problem. Vidare kan Antons beskrivning av sina kroppsliga erfarenheter till mig ses som ett sätt att $\mathrm{i}$ intervjun påtala sin ånger. Att berätta om ånger och ångest för det man gjort är med andra ord en narrativ strategi, ett sätt att uppvisa det skamliga i sina handlingar. Genom synbar ånger, genom att vara beredd att ta sitt straff och gå i behandling är det möjligt för Anton att berätta och offentliggöra sitt våld samtidigt som han gör sig själv begriplig.

\section{Diskussion}

Denna artikel har analyserat hur män som utövat våld mot kvinnor förväntar sig och upplever det sociala nätverkets respons, hur dessa män berättar om våldet och hur berättandet påverkar responsen; i synnerhet diskuteras skammens betydelse i berättandet.

Männen i studien förväntar sig att bli kritiserade och fördömda av sina bekanta. Detta grundar sig i att de ser våldet som något som går på tvärs med deras och vad de förmodar är andras åsikt om korrekt manligt beteende. Män bör enligt dessa kulturella normer inte slå kvinnliga partners eftersom de ses som svagare och eftersom parrelationer bör präglas av ömsesidig respekt. Männen förmodar att människor runt omkring dem inte bara kommer att kritisera handlingen utan också ta avstånd från dem som personer, eller åtminstone att relationerna kommer att försämras när de får kunskap om våldet. Männen är alltså rädda för att våldet inte enbart ska förstås som en moraliskt förkastlig handling, utan rädslan är att det också ska kopplas samman med deras personlighet. Deras rädsla gäller därmed utsikten att bli betraktade som kvinnomisshandlare snarare än som män som utövat våld. I linje med Scheffs (2003a, 2003b) resonemang om skam och sociala relationer, grundar sig våldets skam med andra ord i att männens sociala band riskeras eftersom de förmodar att ingen runt omkring dem vill ha med en kvinnomisshandlare att göra. I likhet med manliga och kvinnliga våldsoffer (Enander 2010; Fiene 1995; Weiss 2010) resulterar denna upplevelse av skam i att männen generellt är försiktiga med att berätta om sina handlingar för det sociala nätverket.

Vidare har denna artikel visat att männen inte får de former av negativ respons de förväntat sig, men till skillnad från männen i exempelvis Schwartz och DeKeseredys (1997) studie får de inte något stöd som godkänner och därmed upprätthåller våldet. Istället möts de av ett generellt fördömande av våld, att våld mot kvinnor är fel. På så sätt skulle man kunna förmoda att de möts av respons och stöd som kan få våldet att upphöra (Hearn 1998b). Men resultaten visar på att skillnaderna mellan stöd som upprätthåller våld och som får våldet att upphöra är små. Männen beskriver hur de oftast initialt möts av ett generellt fördömande av våld, men att de samtidigt möts av förståelse för, och ett begripliggörande av, den enskilde mannen och hans handlingar. 
Detta har jag visat på hör nära samman med de sätt männen presenterar sitt våld. De använder olika former av narrativa strategier som hanterar det förmodade utpekandet av våldet som skamligt. De fyra narrativa strategier som identifierats i denna studie är: att omdefiniera, kontextualisera och fördöma våldet, samt att visa på det skamliga i sina handlingar. Genom att omdefiniera och kontextualisera våldet kan männen tona ned allvaret och omfattningen på våldet och rikta uppmärksamheten mot annat. Dessa narrativa strategier får mannens våld att framstå som det oundvikliga resultatet av svåra omständigheter eller som en bisak till vad de upplever är det verkliga problemet. Det hjälper männen att hantera vad de förmodar är det sociala nätverkets negativa respons och att undvika det skamliga utpekandet som kvinnomisshandlare. Upplevelsen av skam utgör således ett hinder för männen att helt öppet berätta om sitt våld, utan istället används de narrativa strategierna för att visa på att man inte är en "riktig" kvinnomisshandlare. Men skam kan också användas som en narrativ strategi när männen berättar om sitt våld. Detta sker bland annat genom att visa på eller beskriva sin ånger och sin skam, och genom att fördöma sina egna handlingar.

Att uppvisa skam i berättandet kring sitt våld hanterar en central fråga i skamupplevelsen, nämligen sammankopplingen mellan moraliskt felaktiga handlingar och jaget (Leeming \& Boyle 2013; Lewis 1992; Scheff 2003a). Genom uppvisandet av skam blir det möjligt för mannen att fördöma handlingarna som moraliskt problematiska samtidigt som han begripliggör sig själv. Han uppvisar en "begriplig" känsla och visar att han begriper att det han gjort mot sin partner är fel (jfr Karstedt 2002). Jaget och handlingarna skiljs på så sätt åt, mannen förkroppsligar inte det problematiska maskulina kvinnomisshandlarsubjektet utan genom att ställa sig på sina vänners och familjs sida och fördöma detta subjekt föregriper han inte bara fördömandet utan iscensätter sig också som en "normal" man som på grund av omständigheter eller "aggressionsproblem" blivit våldsam. En narrativ framställning av mannen som normal möjliggör en distansering till en stereotyp förövarroll (Ekström 2004). På så sätt kan mannen lösgöra sina handlingar från sitt jag. Han är inte en kvinnomisshandlare, utan egentligen en "normal" och "snäll" man som utfört hemska handlingar. Skam blir då inte bara ett resultat av att de sociala banden hotas, utan uppvisandet av skam utgör då också en resurs för att hantera hotade sociala band.

\section{Referenser}

Altonen, M., Kivivouri, J., Martikainen, P. \& Salmi, V. (2012). Socio-economic status and criminality as predictors of male violence: Does victim's gender or place of occurence matter? British Journal of Criminology vol. 52, nr. 6, ss. 1192-1211.
Ashley, O. \& Foshee, V. (2005). Adolescent help-seeking for dating violence: Prevalence, sociodemographic correlates, and sources of help. Journal of Adolescent Health vol. 36, nr. 1, ss. 25-31.

Braithwaite, J. (1989). Crime, shame and reintegra- 
tion. Cambridge: Cambridge University Press.

Brå (2013) Nationella trygghetsundersökningen 2012. Om utsatthet, trygghet och förtroende (Rapport 2013:1). Stockholm: Brottsförebyggande rådet.

Connell, R.W. (2002). On hegemonic masculinity and violence: Response to Jefferson and Hall. Theoretical Criminology vol. 6, nr. 1, ss. 89-99.

DeKeseredy, W. \& Schwartz, M. (2005). Masculinities and interpersonal violence. I Kimmel, M., Hearn, J. \& Connell, R.W. (red.) Handbook of studies on men and masculinities. Thousand Oaks: Sage.

Dutton, D. (1995). The batterer: A psychological profile. New York: Basic Books.

Enander, V. (2010). "A fool to keep staying": Battered women labeling themselves stupid as an expression of gendered shame. Violence Against Women vol. 16, nr. 1, ss. 5-31.

Ekström, S. (2004). Kajsa bara jamade - om text och undertext i våldtäktsärenden. Tidskrift utgiven av juridiska föreningen $i$ Finland: JFT nr. 6, ss. 704-726.

Eriksson, M. (2003). I skuggan av pappa. Familjerätten och hanteringen av fäders vaild (Diss.). Stehag: Gondolin.

Fiene, J. (1995). Battered women: Keeping the secret. Affilia vol. 10, nr. 2, ss. 179-193.

Fine, G. A. \& Kleinman, S. (1983) Network and meaning: An interactionist approach to structure. Symbolic Interaction vol. 6, nr. 1, ss. 97-110.

German, T. (2006). Male batterers' perceptions of criticism and support from family and friends (Diss.). Boston: Dept. of Sociology, Boston University.

Goffman, E. (1970). När människor möts. Studiet av det direkta samspelet mellan människor. Stockholm: Bonnier.

Gottzén, L. (2012). Att (inte) bli en kvinnomisshandlare. I Gottzén, L. \& Jonsson, R. (red.) Andra män. Maskulinitet, normskapande och jämställdhet. Malmö: Gleerups.

Gottzén, L. (2013). Encountering violent men: Strange and familiar. I Pini, B. \& Pease, B. (red.) Men, masculinities and methodologies. London
\& New York: Palgrave Macmillan.

Gottzén, L. \& Jonsson, R. (red.) (2012). Goda män och Andra män. I Andra män. Maskulinitet, normskapande och jämställdhet. Malmö: Gleerups.

Gottzén, L. \& Korkmaz, S. (2013) Killars våld mot tjejer i nära relationer. I Unga och våld - en analys av maskulinitet och förebyggande verksamheter. Stockholm: Norstedts juridik.

Gubrium, J. \& Holstein, J. (2008). Analyzing narrative reality. Thousand Oaks: Sage.

Hearn, J. (1998a). The violences of men: How men talk about and how agencies respond to men's violence to women. London: Sage.

Hearn, J. (1998b). Men will be men: The ambiguity of men's support for men who have been violent to known women. I Popay, J., Hearn, J. \& Edwards, J. (red.) Men, gender divisions and welfare. London: Routledge.

Hochschild, A. (1983). The managed heart: Commercialization of human feeling. Berkeley: University of California Press.

Hydén, M. (1995). Kvinnomisshandel inom äktenskapet. Mellan det omöjliga och det möjliga. Stockholm: Liber.

Hydén, M. (2000). Att lyssna till en kör av röster: Den berättarfokuserade intervjun. Socialvetenskaplig tidskrift vol. 7, nr. 1-2, ss. 137-158.

Hydén, M. (2005). "I must have been an idiot to let it go on": Agency and positioning in battered women's narratives of leaving. Feminism \& Psychologyvol. 15, nr. 2, ss. 171-190.

Karstedt, S. (2002). Emotions and criminal justice. Theoretical Criminology vol. 6, nr. 3, ss. 299317.

Katz, J. (1999). How emotions work. Chicago: University of Chicago Press.

Klein, R. (2012). Responding to intimate violence against women: The role of informal networks. New York: Cambridge University Press.

Leeming, D. \& Boyle, M. (2013). Managing shame: An interpersonal perspective. British Journal of Social Psychology vol. 52, nr. 1, ss. 140-160.

Lewis, M. (1992). Shame: The exposed self. New York: The Free Press.

Lundgren, E., Heimer, G., Westerstrand, J. \& 
Kalliokoski, A-M (2001). Slagen dam. Mäns våld mot kvinnor $i$ det jämställda Sverige - en omfångsundersökning. Umeå: Brottsoffermyndigheten.

McCarry, M. (2007). Masculinity studies and male violence: Critique or collusion? Women's Studies International Forum vol. 30, nr. 5, ss. 404415.

Proposition 1997/98:55. Kvinnofrid. Stockholm: Fritzes.

Ptacek, J. (1988). Why do men batter their wives? I Yllö, K. \& Bograd, M. (red.) Feminist perspectives on wife abuse. Newbury Park: Sage.

Riessman, C. K. (2008). Narrative methods for the human sciences. Thousand Oaks: Sage.

Scheff, T. (2003a). Shame in self and society. Symbolic Interaction vol. 26, nr. 2, ss. 239-262.

Scheff, T. (2003b). Male emotions/relationships and violence: A case study. Human Relations vol. 56, nr. 6, ss. 727-749.

Scheff, T. \& Retzinger, S. M. (1991). Emotions and violence: Shame and rage in destructive conflicts. Lexington: Lexington Books.
Schrock, D. \& Padavic, I. (2007). Negotiating hegemonic masculinity in a batterer intervention program. Gender \& Society vol. 21, nr. 5, ss. 625-649.

Schwartz, M. \& DeKeseredy, W. (1997). Sexual assault on college campus: The role of male peer support. Thousand Oaks: Sage.

Smart, C. (2007). Personal life: New directions in sociological thinking. Cambridge: Polity Press.

Waldram, J. (2010). Moral agency, cognitive distortion, and narrative strategy in the rehabilitation of sexual offenders. Ethos vol. 38, nr. 3, ss. 251-274.

Weiss, K. (2010). Too ashamed to report: Deconstructing the shame of sexual victimization. Feminist Criminology vol. 5, nr. 3, ss. 286-310.

Wendt Höjer, M. (2002). Rädslans politik. Våld och sexualitet i den svenska demokratin (Diss.). Malmö: Liber.

Winstok, Z. (2007). Toward an interactional perspective on intimate partner violence. Aggression and Violent Behavior vol. 12, nr. 3, ss. 348363.

\section{Summary}

\section{Shame, masculinity and responses to men's violence against women}

Drawing on qualitative interviews with 44 men in batterer intervention programmes, the present article focuses on responses to men's violence against women, and particularly on violent men's expected and experienced responses from their social networks. The participants see violence against women as morally reprehensible since men are not supposed to use violence against "weaker" individuals (e.g. women) and that couple relationships are supposed to be characterized by mutual respect.
They argue that their social networks share this view of interpersonal violence. As a consequence of breaching cultural norms on violence and gender, the men experience their violence as shameful. Shame is connected to fears of being judged and rejected. The experience of shame causes the men to be wary of telling others about their violence and seeking emotional support from friends and family in order to end violence.

Some men's experiences confirm their 
expected critical response, but most men receive relatively uncritical actual response. These responses are related to different narrative strategies that the men employ when disclosing their violence. The men contextualize their violence by, for instance, emphasizing their personal crisis, addiction, or their partner's provocations. They also redefine their violence, for instance, they talk about their "aggression issues" rather than in terms of assault.
When disclosing their violence, the men may also condemn the violence by emphasizing that they understand that they have acted morally wrong and that they take full responsibility for their violence. Finally, the men may present themselves as remorseful by dealing with their "issues" and being in therapy. By condemning their own actions as shameful, the men are able to align with normative notions of masculinity and make themselves intelligible. 